\title{
Karakteristik Bayi Prematur yang Mengalami Anemia dan Tranfusi PRC Sebelum Usia Kronologis 4 Minggu
}

\author{
Made Satria Murti, Lily Rundjan, Aman Bhakti Pulungan \\ Departemen Ilmu Kesehatan Anak Fakultas Kedokteran Universitas Indonesia / RS. Dr. Cipto Mangunkusumo, Jakarta
}

\begin{abstract}
Latar belakang. Indonesia merupakan salah satu negara di dunia dengan angka kelahiran prematur terbanyak. Salah satu morbiditas yang umum dijumpai adalah anemia. Akibatnya, pasien sering mendapatkan transfusi PRC di minggu pertama kehidupannya. Mencegah anemia akan mengurangi kemungkinan tranfusi dan risiko komplikasinya.

Tujuan. Mengetahui karakteristik bayi prematur yang mengalami anemia dan transfusi PRC sebelum usia kronologis 4 minggu Metode. Studi potong lintang terhadap rekam medis semua bayi baru lahir prematur yang menjalani perawatan di Unit Perinatologi RSCM periode 1 Januari 2012 sampai dengan 31 Desember 2013. Penilaian karakteristik bayi prematur meliputi kadar Hb, berat lahir, usia gestasi, riwayat tranfusi PRC, status sepsis, lama rawat, dan status keluar.

Hasil. Didapatkan 393 subjek memenuhi kriteria penelitian, 94 (23,9\%) anemia dan 123 (31,3\%) minimal satu kali mendapatkan transfusi PRC. Frekuensi tersering anemia dan mendapatkan transfusi PRC berturut-turut adalah 4 dan 7 kali. Usia pertama kali mengalami anemia dan transfusi PRC adalah usia $\leq 7$ hari Variabel dengan perbedaan proporsi karakteristik yang sama menunjukkan hasil bermakna secara statistik adalah variabel usia gestasi, berat lahir, transfusi PRC, status sepsis, lama rawat, dan status keluar.

Kesimpulan. Insiden bayi prematur yang mengalami anemia 23,9\%, sedangkan insiden transfusi PRC 31,3\%. Kejadian anemia dan transfusi PRC paling banyak dialami pada satu minggu pertama kehidupan. Perbedaan proporsi antar variabel untuk kejadian anemia dan kejadian transfusi PRC secara statistik bermakna ditemukan pada variabel yang sama, yaitu usia gestasi, berat lahir, status sepsis, lama rawat, dan status keluar. Sari Pediatri 2015;17(2):81-8.
\end{abstract}

Kata kunci: anemia, bayi prematur, transfusi PRC, karakteristik, insiden

\section{Characteristic of Premature infants with Anemia and PRC Transfusion before 4 Week Chronological Age}

\author{
Made Satria Murti, Lily Rundjan, Aman Bhakti Pulungan
}

Background. Indonesia is one of the 11 countries with high number of premature birth rates. One of the morbidity commonly seen ini premature infants is anemia. This cause frequent blood transfusion during their first weeks of life. Anemia prevention will reduce transfusion and its complication.

Objectives. To study characteristics of premature infants with anemia and PRC transfusion before 4 week of chronological age in Perinatology Unit Cipto Mangunkusumo Hospital, Jakarta.

Methods. A cross-sectional study of medical records of newborn premature infants hospitalized in perinatology unit Cipto Mangunkusumo Hospital Jakarta from January $1^{\text {st }}$, 2012 until December 31 $1^{\text {st }}$, 2013. Subjects were selected by simple random sampling. Characteristics evaluation includes $\mathrm{Hb}$ concentration, birth weight, gestational age, PRC transfusion status, sepsis status, length of hospital stay, and discharge status.

Results. There were 393 medical records of subjects included for analysis, with 94 (23,9\%) cases of anemia and $123(31,3 \%)$ cases receiving at least once PRC transfusion. The most frequent anemia episode was 4 times, while PRC transfusion most frequent transfusion was 7 times. First episode of anemia and PRC transfusion were found mostly at age $\leq 7$ days. Statistically significant difference in proportion of anemia was shown in variables gender, gestational age, birth weight, PRC transfusion status, sepsis status, length of stay, and discharge status. While difference in proportion of PRC transfusion was statistically significant in variables gestational age, birth weight, PRC transfusion, septic status, length of stay, and discharge status. Conclusions. Incidence of anemia in premature infants was $23,9 \%$ while incidence of PRC transfusion was $31,3 \%$. First episode of anemia and PRC transfusion were mostly found at the first week of life. Difference in proportion of anemia and PRC transfusion have similar significant result in variables of gestational age, birth weight, sepsis status, length of stay, and discharge status. Sari Pediatri 2015;17(2):81-8.

Keywords: anemia in premature infant, PRC transfusion, characteristic, incidence, Hb concentration

Alamat korespondensi: Dr. Made Satria Murti, Sp.A. Departemen Ilmu Kesehatan Anak FKUI, Jakarta, Indonesia Jalan Diponegoro no.71, Jakarta, 10430, Indonesia. Telp +62-21-3907742, Fax +62-21-3907743. E-mail:madesatria_m@yahoo.co.id 
$\mathrm{P}$ rematuritas adalah penyebab terbesar kematian neonatus di dunia dan peringkat kedua penyebab kematian anak di bawah usia 5 tahun setelah pneumonia. Indonesia merupakan salah satu dari 11 negara di dunia yang memiliki angka kelahiran prematur terbanyak, yaitu $>15 \%$ dari seluruh kelahiran hidup. ${ }^{1-3}$ Bayi prematur memiliki risiko untuk mengalami berbagai morbiditas dan mortalitas pasca lahir. Anemia merupakan salah satu komplikasi yang sering dialami oleh bayi prematur. ${ }^{1,4}$ Anemia yang dialami bayi prematur merupakan anemia yang paling sering ditemukan pada bayi baru lahir terutama bayi dengan usia gestasi kurang dari 32 minggu. ${ }^{5}$ Dalam penelitiannya, De Freitas $\mathrm{dkk}^{6}$ mendapatkan $39,4 \%$ bayi prematur memperoleh transfusi sel darah merah (packed red cell/PRC) minimal satu kali selama perawatan. Sementara itu, dalam penelitian yang lain terhadap bayi dengan berat lahir kurang dari 1500 gram, Jeon $\mathrm{dkk}^{7}$ mendapatkan $78 \%$ subjek mengalami tranfusi minimal satu kali selama perawatan.

Transfusi PRC merupakan salah satu tata laksana yang diberikan pada neonatus dengan anemia, dan hingga saat ini masih menjadi terapi pilihan pada bayi prematur yang mengalami anemia. ${ }^{8}$ Bayi prematur merupakan salah satu populasi pasien terbanyak yang mendapatkan transfusi. ${ }^{9-11}$ Transfusi pada kelompok usia ini sebagian besar terjadi pada minggu pertama kehidupannya. ${ }^{11,12}$ Mencegah anemia akan mengurangi kemungkinan bayi prematur mendapatkan transfusi serta akan menurunkan risiko komplikasi transfusi. Secara umum, anemia didefinisikan sebagai keadaan konsentrasi $\mathrm{Hb}$ atau hematokrit $(\mathrm{Ht})$ lebih dari 2 simpang baku di bawah rentang normal sesuai dengan umur..$^{14}$ Berbeda dengan anemia pada umumnya, untuk menilai apakah kadar $\mathrm{Hb} / \mathrm{Ht}$ pada neonatus sudah cukup rendah hingga dapat disebut anemia, harus memperhatikan juga kondisi berat lahir, usia gestasi, dan usia kronologis neonatus tersebut. ${ }^{11,15}$ Beberapa kepustakaan yang hanya mencantumkan nilai rujukan kadar $\mathrm{Hb}$ berdasarkan usia gestasi untuk hari pertama saja. Sementara kepustakaan lainnya menyebutkan rentang rujukan kadar $\mathrm{Hb}$ bayi prematur dengan hanya mempertimbangkan usia kronologisnya saja (Tabel 1).

\section{Metode}

Penelitian potong lintang dengan pemilihan subjek secara simple random sampling terhadap data rekam medis bayi yang menjalani perawatan di Unit Perinatologi RSCM Jakarta pada periode 1 Januari 2012 hingga 31 Desember 2013. Besar sampel ditentukan menggunakan rumus sampel tunggal untuk estimasi proporsi suatu populasi. Kriteria inklusi adalah bayi dengan riwayat kelahiran prematur, bayi dirawat di unit Perinatologi RSCM, bayi memiliki data pemeriksaan $\mathrm{Hb}$ dalam usia kronologis $\leq 4$ minggu. Pengambilan data setiap subjek penelitian meliputi identitas bayi kadar $\mathrm{Hb}$, usia gestasi, berat lahir, kejadian transfusi PRC, status sepsis, lama rawat dan status subjek saat keluar rumah sakit.

Penelitian ini merupakan deskriptif retrospektif sehingga data yang diambil adalah kumpulan data retrospektif yang berasal dari rekam medis RSCM, data yang diperoleh hanya terbatas dengan apa yang tercantum dalam rekam medis. Penentuan anemia didasarkan pada hasil pemeriksaan kadar $\mathrm{Hb}$. Pemeriksaan kadar $\mathrm{Hb}$ bukanlah pemeriksaan yang selalu dilakukan. Pemeriksaan kadar Hb menjadi bagian dari pemeriksaan rutin hanya terhadap bayi yang dicurigai secara klinis bermasalah. Kondisi tersebut menyebabkan profil anemia pada penelitian ini lebih menggambarkan kondisi anemia yang terjadi pada bayi dengan kondisi medis tertentu.

Nilai kadar $\mathrm{Hb}$ yang didapat merupakan hasil pemeriksaan salah satu dari tiga laboratorium di RSCM, yaitu perinatologi, patologi klinik $24 \mathrm{jam}$, dan instalasi gawat darurat (IGD). Data yang ideal hasil pemeriksaan kadar $\mathrm{Hb}$ adalah hasil tertulis (print-out) dari setiap laboratorium. Namun, seringkali hasil tersebut tidak ditemukan sehingga catatan dokter, perawat, dan atau kombinasi keduanya menjadi alternatif pengambilan data hasil laboratorium. Dalam penelitian ini didapatkan 1012 bayi prematur yang dirawat di Unit Perinatologi RSCM pada periode 1 Januari 2012 hingga 31 Desember 2013. Sebanyak 393 subjek yang memenuhi kriteria penelitian terpilih pada penelitian ini dengan 94 $(23,9 \%)$ subjek diantaranya mengalami anemia. Anemia dalam penelitian ini adalah keadaan kadar Hb lebih dari 2 simpang baku di bawah rentang normal berdasarkan rujukan dan dikelompokkan sebagai berikut. Pada usia kronologis $<1$ hari jika $\mathrm{Hb}<12,8 \mathrm{~g} / \mathrm{dL} ; 1-7$ hari jika $\mathrm{Hb}$ $<10,5 \mathrm{~g} / \mathrm{dL} ; 8-14$ hari jika $\mathrm{Hb}<9,7 \mathrm{~g} / \mathrm{dL} ; 15-22$ hari jika $\mathrm{Hb}<8,9 \mathrm{~g} / \mathrm{dL}$, dan 22-28 hari jika $\mathrm{Hb}<7,1 \mathrm{~g} / \mathrm{dL}$.

Data diolah dengan menggunakan program SPSS versi 17. Hubungan antara dua variabel kualitatif dianalisis dengan uji chi square. Batas kemaknaan yang digunakan adalah alpha 5\% untuk interpretasi data. Data disajikan secara tekstular dan tabular. Persetujuan 
etik penelitian diperoleh dari Komisi Etik penelitian Fakultas Kedokteran Universitas Indonesia/RSUPN Cipto mangunkusumo, Jakarta, Indonesia.

\section{Hasil}

Penelusuran rekam medis secara fisik menghasilkan 393 rekam medis yang memenuhi kriteria penelitian. Didapatkan insiden bayi prematur yang mengalami anemia sebelum usia kronologis 4 minggu $23,9 \%$ (94 subjek dari 393 total subjek penelitian)(Gambar 1). Median usia subjek saat pertama kali mengalami anemia adalah 5 hari (0-28 hari) dengan kelompok usia $\leq 7$ hari 62 (66\%), kelompok usia 8-14 hari 14 $(14,9 \%)$, kelompok usia $15-21$ hari 10 (10,6\%), dan kelompok usia 22-28 hari 8 (8,5\%)(Tabel 2).

Karakteristik subjek dengan anemia berjumlah 94. Frekuensi anemia 1x, 2x, 3x, dan 4x berturut-turut 74 (78,7\%), $18(19,1 \%), 1(1,1 \%)$, dan $1(1,1 \%)$. Usia pertama kali anemia (hari) $\leq 7,8-14,15-21$, dan $22-28$ berturut-turut 62 (66\%), 14 (14,9\%), 10 (10,6\%), dan $8(8,5 \%)$. Perbedaan proporsi antar frekuensi anemia dibandingkan dengan variabel usia gestasi dan berat lahir. Frekuensi anemia secara statistik tidak berhubungan bermakna terhadap variabel usia gestasi dan berat lahir (Tabel 3).

Pada penelitian ini didapatkan 123 (31,3\%) subjek pernah mendapatkan transfusi PRC minimal 1 kali selama perawatan (Gambar 2). Frekuensi transfusi PRC tersering adalah 7 kali yang dialami $1(0,8 \%)$ subjek. Median usia subjek saat pertama kali mendapatkan transfusi PRC adalah 6 hari (0-27 hari). Pada kelompok usia $\leq 7$ hari, $63(51,2 \%)$ subjek mendapatkan transfusi
PRC. Karakteristik pemberian transfusi PRC tertera pada Tabel 4.

Didapatkan 31,3\% subjek yang memperoleh transfusi PRC. Perbandingan proporsi antara subjek yang mendapatkan transfusi PRC dengan yang tidak mendapatkan transfusi PRC, meliputi variabel jenis kelamin, usia gestasi, berat lahir, status sepsis, lama rawat, dan status keluar (Tabel 5).

\section{Pembahasan}

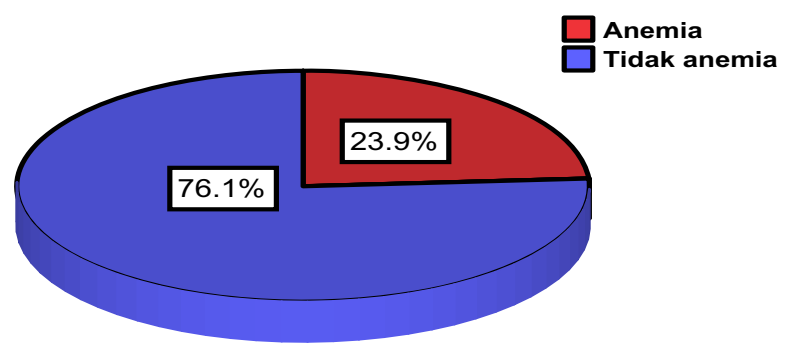

Gambar 1. Insiden bayi prematur yang mengalami anemia

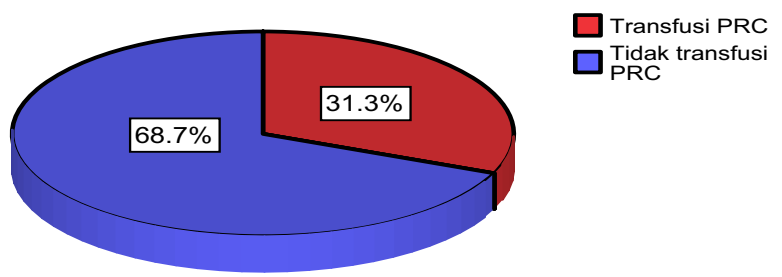

Gambar 2. Insiden transfusi PRC

Tabel 1. Nilai sel darah merah pada bayi prematur ${ }^{17}$

\begin{tabular}{llllll}
\hline Hari & $\mathrm{RBC}\left(\mathrm{x} 10^{6} / \mathrm{uL}\right)$ & $\mathrm{Hb}(\mathrm{g} / \mathrm{dL})$ & $\mathrm{MCV}(\mathrm{fl})$ & $\mathrm{MCH}(\mathrm{pg})$ & $\mathrm{MCHC}(\mathrm{g} / \mathrm{L})$ \\
\hline 1 & $4,71 \pm 0,75$ & $18,2 \pm 2,7$ & $115 \pm 5$ & $38,9 \pm 1,7$ & $33,5 \pm 1,2$ \\
3 & $4,4 \pm 0,83$ & $16,2 \pm 2,9$ & $112 \pm 4$ & $39,0 \pm 3,4$ & $33,8 \pm 1$ \\
7 & $4,45 \pm 0,83$ & $16,3 \pm 2,9$ & $110 \pm 5$ & $37,3 \pm 1,8$ & $33,9 \pm 1,3$ \\
14 & $4,10 \pm 0,69$ & $14,5 \pm 2,4$ & $106 \pm 5$ & $36,3 \pm 1,9$ & $33,9 \pm 1$ \\
21 & $3,71 \pm 0,59$ & $12,9 \pm 2$ & $102 \pm 5$ & $35,3 \pm 2,2$ & $34,2 \pm 1,1$ \\
28 & $3,17 \pm 0,6$ & $10,9 \pm 1,9$ & $100 \pm 5$ & $35,1 \pm 1,9$ & $34,4 \pm 1$ \\
35 & $2,97 \pm 0,45$ & $10 \pm 1,4$ & $98 \pm 5$ & $34,4 \pm 1,5$ & $34,5 \pm 0,7$ \\
42 & $2,94 \pm 0,49$ & $9,5 \pm 1,5$ & $97 \pm 5$ & $32,2 \pm 1,7$ & $33,7 \pm 0,9$ \\
49 & $3,21 \pm 0,59$ & $10,1 \pm 1,7$ & $95 \pm 5$ & $32,1 \pm 1,6$ & $33,5 \pm 1$ \\
\hline
\end{tabular}

$\mathrm{RBC}$, red blood cell count; $\mathrm{Hb}$, hemoglobin; $\mathrm{Ht}$, hematokrit; $\mathrm{MCV}$, mean corpuscular volume; $\mathrm{MCH}$, mean corpuscular hemoglobin; MCHC, mean corpuscular hemoglobin concentration.

Nilai yang ditampilkan adalah nilai rerata \pm simpang baku 
Made Satria Murti dkk: Bayi prematur yang mengalami anemia dan transfusi PRC

Tabel 2. Karakteristik subjek berdasarkan perbedaan proporsi anemia dan tidak anemia $(\mathrm{n}=393)$

\begin{tabular}{|c|c|c|c|}
\hline Karakteristik & $\begin{array}{c}\text { Anemia } \\
\text { n }(\%)\end{array}$ & $\begin{array}{c}\text { Tidak anemia } \\
\mathrm{n}(\%)\end{array}$ & nilai $\mathrm{p}^{*}$ \\
\hline \multicolumn{4}{|l|}{ Jenis kelamin } \\
\hline Laki-laki & $57(28,2)$ & $145(71,8)$ & \multirow[t]{2}{*}{0,04} \\
\hline Perempuan & $37(19,4)$ & $154(80,6)$ & \\
\hline \multicolumn{4}{|l|}{ Usia gestasi (minggu) } \\
\hline$<28$ & $11(28,9)$ & $27(71,1)$ & \multirow[t]{3}{*}{$<0,0001$} \\
\hline $28-<32$ & $41(37,3)$ & $69(62.7)$ & \\
\hline $32-36$ & $42(17,1)$ & $203(82,9)$ & \\
\hline \multicolumn{4}{|l|}{ Berat lahir (gram) } \\
\hline$<1000$ & $10(29,4)$ & $24(70,6)$ & \multirow[t]{5}{*}{$<0,0001$} \\
\hline $1000-1499$ & $38(43,2)$ & $50(56,8)$ & \\
\hline 1500-1999 & $34(20,1)$ & $135(79,9)$ & \\
\hline $2000-2499$ & $11(13,4)$ & $71(86,6)$ & \\
\hline$\geq 2500$ & $1(5)$ & $19(95)$ & \\
\hline \multicolumn{4}{|l|}{ Transfusi PRC } \\
\hline $\mathrm{Ya}$ & $73(59,3)$ & $50(40,7)$ & \multirow[t]{2}{*}{$<0,0001$} \\
\hline Tidak & $21(7,8)$ & $249(92,2)$ & \\
\hline \multicolumn{4}{|l|}{ Status sepsis } \\
\hline Terbukti sepsis & $26(46,4)$ & $30(53,6)$ & \multirow[t]{3}{*}{$<0,0001$} \\
\hline Sepsis klinis & $68(21,1)$ & $254(78,9)$ & \\
\hline Tidak sepsis & $0(0)$ & $15(100)$ & \\
\hline \multicolumn{4}{|l|}{ Lama rawat (hari) } \\
\hline$\leq 7$ & $18(23,4)$ & $59(76,6)$ & \multirow[t]{5}{*}{$<0,0001$} \\
\hline $8-14$ & $13(14,9)$ & $74(85,1)$ & \\
\hline $15-21$ & $12(16,9)$ & $59(83,1)$ & \\
\hline $22-28$ & $7(12,5)$ & $49(87,5)$ & \\
\hline$>28$ & $44(43,1)$ & $58(56,9)$ & \\
\hline \multicolumn{4}{|l|}{ Status keluar rumah sakit } \\
\hline Dipulangkan & $46(18,8)$ & $199(81,2)$ & \multirow[t]{3}{*}{$<0,0001$} \\
\hline Pulang paksa dan transfer & $11(16,7)$ & $55(83,3)$ & \\
\hline Meninggal & $37(45,1)$ & $45(54,9)$ & \\
\hline
\end{tabular}

* uji Pearson chi-square

Tabel 3. Perbedaan proporsi antar frekuensi anemia $(n=94)$

\begin{tabular}{lccc}
\hline Karakteristik & \multicolumn{2}{c}{ Frekuensi anemia } & \multirow{2}{*}{ nilai $\mathrm{p}^{*}$} \\
\cline { 2 - 3 } & $\begin{array}{c}1 \mathrm{kali} \\
\mathrm{n}(\%)\end{array}$ & $\begin{array}{c}>1 \mathrm{kali} \\
\mathrm{n}(\%)\end{array}$ & \\
\hline $\begin{array}{l}\text { Usia gestasi (minggu) } \\
<28\end{array}$ & $7(63,6)$ & $4(36,4)$ & 0,108 \\
$28-<32$ & $30(73,2)$ & $11(26,8)$ & \\
$32-36$ & $37(88,1)$ & $5(11,9)$ & \\
Berat lahir (gram) & & & 0,361 \\
$<1000$ & $7(70)$ & $3(30)$ & \\
$1000-1499$ & $28(73,7)$ & $10(26,3)$ & \\
$\geq 1500$ & $39(84,8)$ & $7(15,2)$ & \\
\hline
\end{tabular}


Tabel 4. Karakteristik transfusi PRC ( $\mathrm{n}=123)$

\begin{tabular}{lcc}
\hline Karakteristik & $\mathrm{n}$ & $\%$ \\
\hline Frekuensi transfusi & & \\
$-1 \mathrm{x}$ & 54 & 43,9 \\
$-2 \mathrm{x}$ & 43 & 35 \\
$-3 \mathrm{x}$ & 10 & 8,1 \\
$-4 \mathrm{x}$ & 10 & 8,1 \\
$-5 \mathrm{x}$ & 4 & 3,3 \\
$-6 \mathrm{x}$ & 1 & 0,8 \\
$-7 \mathrm{x}$ & 1 & 0,8 \\
Usia pertama kali transfusi (hari) & & \\
$-\leq 7$ & 63 & 51,2 \\
$-8-14$ & 31 & 25,2 \\
$-15-21$ & 16 & 13 \\
$-22-28$ & 13 & 10,6 \\
\hline
\end{tabular}

Secara umum, anemia didefinisikan sebagai keadaan konsentrasi $\mathrm{Hb}$ atau $\mathrm{Ht}$ lebih dari 2 simpang baku di bawah rentang normal sesuai dengan usia. ${ }^{14}$ Namun, sedikit berbeda pada bayi baru lahir, terutama bayi prematur. Keputusan menilai kadar $\mathrm{Hb}$ untuk dinyatakan sebagai anemia harus mempertimbangkan berat lahir, usia gestasi, dan usia kronologis bayi. ${ }^{11,15}$ Beberapa kepustakaan mencantumkan nilai rujukan kadar Hb berdasarkan usia gestasi atau berat lahir hanya untuk hari pertama saja. ${ }^{14,16}$ Padahal, secara fisiologis, kadar $\mathrm{Hb}$ akan turun sejalan dengan usia kronologis pasien. Hingga saat ini, belum didapatkan rujukan mengenai nilai optimal rentang kadar $\mathrm{Hb} /$ Ht yang mempertimbangkan semua faktor tersebut hingga dapat dipergunakan pada bayi prematur.

Tabel 5. Karakteristik subjek berdasarkan perbedaan proporsi subjek yang mendapatkan transfusi PRC dengan tanpa transfusi $(\mathrm{n}=393)$

\begin{tabular}{|c|c|c|c|}
\hline Karakteristik & $\begin{array}{c}\text { Transfusi } \\
\mathrm{n}(\%)\end{array}$ & $\begin{array}{c}\text { Tidak transfusi } \\
\mathrm{n}(\%)\end{array}$ & nilai $\mathrm{p}^{*}$ \\
\hline \multicolumn{4}{|l|}{ Jenis kelamin } \\
\hline Laki-laki & $72(35,6)$ & $130(64,4)$ & \multirow[t]{2}{*}{0,056} \\
\hline Perempuan & $51(26,7)$ & $140(73,3)$ & \\
\hline \multicolumn{4}{|l|}{ Usia gestasi (minggu) } \\
\hline$<28$ & $21(55,3)$ & $17(44,7)$ & \multirow[t]{3}{*}{$<0,0001$} \\
\hline $28-<32$ & $59(53,6)$ & $51(46.4)$ & \\
\hline $32-36$ & $43(17,6)$ & $202(82,4)$ & \\
\hline \multicolumn{4}{|l|}{ Berat lahir (gram) } \\
\hline$<1000$ & $18(52,9)$ & $16(47,1)$ & \multirow[t]{5}{*}{$<0,0001$} \\
\hline $1000-1499$ & $50(56,8)$ & $38(43,2)$ & \\
\hline $1500-1999$ & $44(26)$ & $125(74)$ & \\
\hline $2000-2499$ & $10(12,2)$ & $72(87,8)$ & \\
\hline$\geq 2500$ & $1(0,8)$ & $19(99,2)$ & \\
\hline \multicolumn{4}{|l|}{ Status sepsis } \\
\hline Terbukti & $44(78,6)$ & $12(21,4)$ & \multirow[t]{2}{*}{$<0,0001$} \\
\hline Sepsis klinis dan tidak sepsis & $79(23,4)$ & $258(76,6)$ & \\
\hline \multicolumn{4}{|l|}{ Lama rawat (hari) } \\
\hline$\leq 7$ & $18(23,4)$ & $59(76,6)$ & \multirow[t]{5}{*}{$<0,0001$} \\
\hline $8-14$ & $9(10,3)$ & $78(89,7)$ & \\
\hline $15-21$ & $15(21,1)$ & $56(78,9)$ & \\
\hline $22-28$ & $10(17,9)$ & $46(82,1)$ & \\
\hline$>28$ & $71(69,6)$ & $31(30.4)$ & \\
\hline \multicolumn{4}{|l|}{ Status keluar } \\
\hline Dipulangkan & $52(21,2)$ & $193(78,8)$ & \multirow[t]{3}{*}{$<0,0001$} \\
\hline Pulang paksa dan transfer & $16(24,2)$ & $50(75,8)$ & \\
\hline Meninggal & $55(67,1)$ & $27(32,8)$ & \\
\hline
\end{tabular}

* uji Pearson chi-square 
Di Indonesia, belum ada konsensus baik dari UKK Neonatologi maupun UKK Hematologi-Onkologi Ikatan Dokter Anak Indonesia (IDAI). Dalam salah satu kepustakaan didapatkan rentang nilai normal $\mathrm{Hb}$ bayi prematur yang mempertimbangkan juga usia kronologis. ${ }^{17}$ Kekurangan dari rujukan ini adalah tidak mengelompokkan lagi nilai tersebut menurut usia gestasi. Kepustakaan inilah yang dijadikan rujukan untuk menentukan batas anemia dalam penelitian ini.

Insiden anemia sedikit berbeda jika dibandingkan dengan insiden kejadian transfusi PRC. Dalam penelitian ini didapatkan $123(31,3 \%)$ subjek yang mendapatkan transfusi minimal satu kali selama masa neonatus, lebih banyak dibandingkan hanya $23,9 \%$ yang mengalami anemia. Perbedaan angka ini dapat dipahami, mengingat lebih banyak subjek yang mendapatkan transfusi sebelum kadar $\mathrm{Hb}$ turun di bawah nilai batas anemia yang ditetapkan dalam penelitian ini. Limapuluh (40,7\%) dari 123 subjek yang mendapatkan transfusi tidak mengalami anemia. Kondisi sebaliknya juga terjadi meskipun dalam jumlah yang lebih sedikit, terdapat $21(7,8 \%)$ dari 249 subjek yang tidak mendapatkan transfusi merupakan subjek dengan anemia. Hal tersebut biasa terjadi meskipun nilai kadar $\mathrm{Hb}$ di bawah rentang normal, subjek tersebut tidak menunjukkan tanda patologis apapun yang dapat menjadi indikasi pemberian transfusi. Bayi prematur yang tumbuh normal dan disertai toleransi asupan yang baik jarang sekali memerlukan transfusi PRC. ${ }^{23}$ Kepentingan klinis menetapkan nilai kadar $\mathrm{Hb}$ sebagai batas anemia adalah untuk menentukan apakah kadar $\mathrm{Hb}$ seorang bayi prematur termasuk normal atau tidak, mengidentifikasi penyebabnya jika ternyata tidak normal, dan selanjutnya menentukan perlu tidaknya dilakukan intervensi. Transfusi PRC adalah intervensi pilihan utama pada bayi baru lahir yang dianggap mengalami anemia. ${ }^{8}$

Nilai batas $\mathrm{Hb}$ yang digunakan dalam menentukan perlu tidaknya seorang bayi ditransfusi seringkali dicampuradukkan sebagai nilai batas anemia. Padahal, anemia adalah definisi berdasarkan nilai $\mathrm{Hb}$, sedangkan pertimbangan melakukan transfusi tidak hanya melihat nilai $\mathrm{Hb}$ melainkan juga mempertimbangkan keseluruhan kondisi klinis bayi. ${ }^{23}$ Penelitian De Freitas $\mathrm{dkk}^{6}$ mendapatkan 39,4\% bayi prematur yang dirawat memerlukan minimal satu kali transfusi PRC selama dirawat. Perbedaan insiden tersebut kemungkinan disebabkan karena penelitian tersebut tidak mengikutsertakan bayi prematur dengan berat lahir $>2500$ gram. Selain itu, penelitian mereka juga memperhitungkan periode waktu yang lebih lama dari penelitian ini. Pada penelitian kami, bayi prematur dengan berat lahir $>2500$ gram juga ikut dimasukkan dan tindakan transfusi hanya dinilai hingga pasien berusia kronologis 4 minggu.

Frekuensi terbanyak seorang subjek mengalami episode anemia adalah 4 kali (1 subjek), lebih sedikit dibandingkan frekuensi terbanyak seorang subjek mendapatkan transfusi PRC, yaitu 7 kali (1 subjek). Subjek yang mengalami episode anemia hingga 4 kali adalah subjek yang sama seperti subjek yang mendapatkan transfusi PRC hingga 7 kali. Pada subjek ini, semua episode anemia yang dialaminya mendapat terapi transfusi PRC, sedangkan 3 transfusi lainnya diberikan saat nilai $\mathrm{Hb}$ belum berada di bawah batas anemia. Hal ini kembali menegaskan bahwa ada kondisi klinis lain yang lebih menjadi pertimbangan dalam memberikan transfusi PRC pada bayi prematur.

Kami mendapatkan 62 (66\%) dari 94 subjek mengalami anemia pertama kali di minggu pertama kehidupannya. Angka yang hampir sama didapatkan pada kejadian transfusi PRC, yaitu $63(51,2 \%)$ dari 123 subjek yang mendapatkan transfusi PRC pertama kali pada minggu pertama kehidupannya. Anemia pada masa neonatus dapat disebabkan oleh kehilangan darah akut atau kronik, proses hemolisis, dan produksi sel darah merah yang berkurang. Proses kehilangan darah pada bayi prematur dapat diakibatkan beberapa sebab, antara lain twin-to-twin transfusion syndrome, prolaps tali pusat, plasenta previa, dan lain-lain. Proses hemolisis dapat disebabkan oleh inkompatibilitas rhesus atau $\mathrm{ABO}$, proses hemolisis akibat infeksi ataupun akibat kelainan pada sel darah merah (defek membran, abnormalitas enzim). Sebaliknya, kegagalan produksi sel darah merah dapat terjadi akibat kelainan pada sumsum tulang, seperti anemia DiamondBlackfan, dan juga akibat proses infeksi., ${ }^{5,16}$

Berdasarkan diagnosis ibu, dari 62 subjek yang mengalami anemia di minggu pertama pasca lahir, terdapat 6 subjek dengan riwayat ibu mengalami perdarahan ante partum berupa plasenta previa dan 2 subjek tersangka twin-to-twin transfusion syndrome. Sementara itu, subjek yang didiagnosis mengalami perdarahan berjumlah $37,1 \%$ (23 dari 62 subjek). Diagnosis perdarahan meliputi saluran cerna, paru, intraventrikular, kulit/hematoma, gangguan faktor koagulasi, dan pasca operasi. Di lain pihak, meskipun 
hanya terdapat $11(17,7 \%)$ subjek yang terbukti sepsis, secara klinis semua subjek pada kelompok ini didiagnosis sepsis. Menurut kepustakaan yang ada, hasil penelitian ini tampak sedikit berbeda. Pada minggu pertama hingga minggu kedua setelah lahir, bayi prematur terutama dengan berat lahir rendah yang dirawat di unit perawatan intensif seringkali mengalami anemia akibat tindakan flebotomi. Sekitar 50\% dari bayi ini akan mendapatkan transfusi PRC pertama mereka pada 2 minggu pertama kehidupannya. ${ }^{11,24}$ Namun, di institusi tempat penelitian ini berlangsung, kondisi sepsis lebih berperan terhadap kejadian anemia dan transfusi PRC. Seperti diketahui, angka kejadian infeksi perinatal masih cukup tinggi di Indonesia dan hal ini mungkin yang menyebabkan tingginya angka kejadian anemia dan transfusi PRC pada satu minggu pertama kehidupan. Selain itu, perbedaan yang ada mungkin juga terkait dengan perbedaan fasilitas unit rawat intensif masing-masing institusi. Beberapa penelitian yang menjadi rujukan dalam kepustakaan dilakukan di negara yang relatif lebih maju fasilitas unit rawat intensifnya.

Kami mendapatkan $94(23,9 \%)$ subjek yang mengalami anemia dan $123(31,3 \%)$ subjek yang mendapatkan transfusi PRC. Perbandingan proporsi subjek yang mengalami anemia dengan subjek yang tidak mengalami anemia menunjukkan perbedaan pada variabel jenis kelamin, usia gestasi, berat lahir, status sepsis, lama rawat, dan status keluar. Hasil yang hampir sama juga didapatkan pada pemberian transfusi PRC. Perbandingan proporsi subjek yang mendapatkan transfusi PRC dengan yang tidak mendapatkan transfusi PRC menunjukkan perbedaan pada variabel usia gestasi, berat lahir, status sepsis, lama rawat, dan status keluar. Hasil penelitian kami hampir sama dengan beberapa penelitian yang telah ada sebelumnya. De Freitas $\mathrm{dkk}^{6}$ melakukan penelitian terhadap 254 subjek bayi prematur di Brasil. Berdasarkan hasil analisis univariat pada beberapa variabel didapatkan bahwa transfusi PRC berhubungan dengan usia gestasi, berat lahir dan kejadian sepsis awitan lambat. Penelitian lain oleh Paul dkk ${ }^{25}$ terhadap 199 bayi berat lahir rendah (BBLR) yang dirawat di neonatal intensive care unit (NICU) mendapatkan beberapa faktor yang berhubungan secara independen dengan kejadian transfusi di antaranya adalah berat lahir dan lama perawatan di rumah sakit. Pada penelitian Jeon $\mathrm{dkk}^{7}$ terhadap 50 bayi prematur BBLR, didapatkan kelompok subjek yang mendapatkan transfusi PRC memiliki usia gestasi dan berat lahir yang lebih kecil, kejadian sepsis yang lebih sering dan lama rawat yang lebih panjang dibandingkan kelompok subjek yang tidak mendapatkan transfusi PRC.

\section{Kesimpulan}

Insiden bayi prematur yang mengalami anemia $23,9 \%$, sedangkan insiden transfusi PRC $31,3 \%$. Kejadian anemia dan transfusi PRC paling banyak dialami pada satu minggu pertama kehidupan. Perbedaan proporsi antar variabel untuk kejadian anemia dan kejadian transfusi PRC secara statistik bermakna ditemukan pada variabel yang sama, yaitu usia gestasi, berat lahir, status sepsis, lama rawat, dan status keluar.

\section{Daftar pustaka}

1. March of Dimes, PMNCH, Save the Children, WHO. Born too soon: the global action report on preterm birth. Geneva: World Health Organization; 2012.

2. Kementerian Kesehatan Republik Indonesia. Profil Data Kesehatan Indonesia Tahun 2011. Jakarta: Kementerian Kesehatan Republik Indonesia; 2012.

3. Blencowe H, Cousens S, Oestergaard MZ, Chou D, Moller A-B, Narwal R, dkk. National, regional, and worldwide estimates of preterm birth rates in the year 2010 with time trends since 1990 for selected countries: a systematic analysis and implications. Lancet 2012;379:2162-72.

4. Eichenwald EC, Stark AR. Management and outcomes of very low birth weight. N Eng J Med 2008;358:170011.

5. Hafidh Y, Hidayah DS. Anemia pada bayi baru lahir. Dalam: Kosim S, Yunanto A, Dewi R, penyunting. Buku ajar neonatologi. Edisi Pertama. Jakarta: Badan Penerbit IDAI; 2008. h.199-200.

6. De Freitas BAC, Franceschini SDCC. Factors associated with packed red blood cell transfusions in premature infants in an intensive care unit. Rev Bras Ter Intensiva 2012;24:224-9.

7. Jeon GW, Sin JB. Risk factors of transfusion in anemia of very low birth weight infants. Yonsei Med J 2013;54:366-73.

8. Fredrickson LK, Bell EF, Cress G a, Johnson KJ, Zimmerman MB, Mahoney LT, dkk. Acute physiological effects of packed red blood cell transfusion in preterm 
infants with different degrees of anaemia. Arch Dis Child Fetal Neonatal Ed 2011;96:F249-53.

9. Luban NLC. Management of anemia in the newborn. Early Hum Dev 2008;84:493-8.

10. Bell E, Strauss R, Widness J, Mahoney L, Mock D, Seward V, dkk. Randomized trial of liberal versus restrictive guidelines for red blood cell transfusion in preterm infants. Pediatrics 2005;115:1685-91.

11. Widness J. Pathophysiology, diagnosis, and prevention of neonatal anemia. Neoreviews 2000;1:61-8.

12. Strauss RG. Anaemia of prematurity: pathophysiology \& treatment. Blood Rev 2010;24:221-5.

13. Guillén Ú, Cummings JJ, Bell EF, Hosono S, Frantz AR, Maier RF, dkk. International survey of transfusion practices for extremely premature infants. Semin Perinatol 2012;36:244-7.

14. Luchtman-Jones L, Wilson DB. Hematologic problems in the fetus dan neonate. Dalam: Martin RJ, Fanaroff AA, Walsh MC, penyunting. Fanaroff and Martin's neonatalperinatal medicine. Edisi ke-9. Missouri: Mosby Elsevier; 2011. h.1303-60.

15. Jopling J, Henry E, Wiedmeier SE, Christensen RD. Reference ranges for hematocrit and blood hemoglobin concentration during the neonatal period: Data from a multihospital health care system. Pediatrics 2009;123:e333-7.

16. Brugnara C, Platt OS. The neonatal erythrocyte and its disorders. Dalam: Orkin S, Nathan D, Ginsburg D, Look A, Fisher D, Lux S, penyunting. Nathan and Oski's hematology of infancy and childhood. Edisi ke-7. Philadelphia: Saunders; 2009. h.21-66.

17. De Alarcon PA, Johnson C, Werner EJ. Eruthropoiesis, red cells, and the approach to anemia. Dalam: De Alarcon PA, Werner EJ, penyunting. Neonatal Hematology. Cambridge: Cambridge University Press; 2005. h.40-57.
18. Widness JA. Pathophysiology of Anemia During the Neonatal Period, Including Anemia of Prematurity. Neoreviews 2008;9:e520-e525.

19. Akter S, Hossain MM, Shirin M, Khalil I, Anwar KS. Blood transfusion: A risk factor in retinopathy of prematurity. J Child Heal 2010;34:38-43.

20. Ke X, Ju R, Zhang J, Chen H, Wei E, Chen X. Risk factors for severe retinopathy of prematurity in premature infants: A single-center study. J South Med Univ 2011;31:1963-7.

21. Aher S, Ohlsson A. Late erythropoietin for preventing red blood cell transfusion in preterm and/or low birth weight infants. Cochrane Database Syst Rev 2012;issue 9:1-22.

22. Ohlsson A, Aher S. Early erythropoietin for preventing red blood cell transfusion in preterm and / or low birth weight infants. Cochrane Database Syst Rev 2012;issue 9:1-11.

23. Lerner NB. Physiologic Anemia of Infancy. Dalam: Kliegman RM, Stanton BF, St.Geme JW, Schor NF, Behrman RE, penyunting. Nelson textbook of pediatrics. Edisi ke-19. Philadelphia: Elsevier Inc.; 2011. h. 1654-5.

24. Bishara N, Ohls RK. Current controversies in the management of the anemia of prematurity. Semin Perinatol 2009;33:29-34.

25. Paul DA, Pearlman SA, Leef KH, Stefano JL. Predicting red blood cell transfusions in very low birth weight infants based on clinical risk factors. Del Med J 1997;69:555-61.

26. Dos Santos AMN, Guinsburg R, de Almeida MFB, Procianoy RS, Leone CR, Marba STM, dkk. Red blood cell transfusions are independently associated with intrahospital mortality in very low birth weight preterm infants. J Pediatr 2011;159:371-376.e1-3. 